\title{
Blâmont Est
}

Thiébauménil

Christophe Card et Philippe Mervelet

\section{(2) OpenEdition}

1 Journals

Édition électronique

URL : http://journals.openedition.org/adlfi/8960

ISSN : 2114-0502

Éditeur

Ministère de la culture

Référence électronique

Christophe Card et Philippe Mervelet, «Blâmont Est », ADLFI. Archéologie de la France - Informations [En ligne], Lorraine, mis en ligne le 01 mars 2001, consulté le 20 avril 2019. URL : http://

journals.openedition.org/adlfi/8960

Ce document a été généré automatiquement le 20 avril 2019.

(c) Ministère de la Culture et de la Communication, CNRS 


\section{Blâmont Est}

Thiébauménil

\section{Christophe Card et Philippe Mervelet}

Identifiant de l'opération archéologique : F1354200100003

Date de l'opération : 2001 - 2002 (EX)

1 Les fouilles d'évaluation préalables à la réalisation de la RN 4 entre Thiébauménil et Blâmont Est se sont déroulées en trois phases (deux en 2001 et une en 2002). La première phase, menée sous la responsabilité de Philippe Mervelet, a concerné la déviation de Bénaménil : 42 ha sondés sur environ $5200 \mathrm{~m}$ de long. La deuxième phase, dirigée par Christophe Card, a porté sur deux secteurs : celui allant de l'ancienne RN 4 à la Vezouze ( $2 \mathrm{~km}$ de long) et un secteur de $600 \mathrm{~m}$ de long au nord de Blâmont. Aucun vestige archéologique n'a été reconnu lors de ces deux opérations.

INDEX

Index géographique : Lorraine, Meurthe-et-Moselle (54), Blâmont operation Expertise (EX)

\section{AUTEURS}

CHRISTOPHE CARD

SRA 
PHILIPPE MERVELET

SRA 